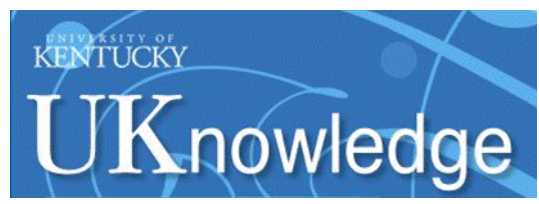

University of Kentucky

UKnowledge

\title{
ROMANTIC ATTACHMENT AMONG YOUNG ADULTS: THE EFFECTS OF PARENTAL DIVORCE AND RESIDENTIAL INSTABILITY
}

Katherine N. Washington

University of Kentucky, knte222@uky.edu

Right click to open a feedback form in a new tab to let us know how this document benefits you.

\section{Recommended Citation}

Washington, Katherine N., "ROMANTIC ATTACHMENT AMONG YOUNG ADULTS: THE EFFECTS OF PARENTAL DIVORCE AND RESIDENTIAL INSTABILITY" (2012). Theses and Dissertations--Family Sciences. 5.

https://uknowledge.uky.edu/hes_etds/5

This Master's Thesis is brought to you for free and open access by the Family Sciences at UKnowledge. It has been accepted for inclusion in Theses and Dissertations--Family Sciences by an authorized administrator of UKnowledge. For more information, please contact UKnowledge@lsv.uky.edu. 


\section{STUDENT AGREEMENT:}

I represent that my thesis or dissertation and abstract are my original work. Proper attribution has been given to all outside sources. I understand that I am solely responsible for obtaining any needed copyright permissions. I have obtained and attached hereto needed written permission statements(s) from the owner(s) of each third-party copyrighted matter to be included in my work, allowing electronic distribution (if such use is not permitted by the fair use doctrine).

I hereby grant to The University of Kentucky and its agents the non-exclusive license to archive and make accessible my work in whole or in part in all forms of media, now or hereafter known. I agree that the document mentioned above may be made available immediately for worldwide access unless a preapproved embargo applies.

I retain all other ownership rights to the copyright of my work. I also retain the right to use in future works (such as articles or books) all or part of my work. I understand that I am free to register the copyright to my work.

\section{REVIEW, APPROVAL AND ACCEPTANCE}

The document mentioned above has been reviewed and accepted by the student's advisor, on behalf of the advisory committee, and by the Director of Graduate Studies (DGS), on behalf of the program; we verify that this is the final, approved version of the student's dissertation including all changes required by the advisory committee. The undersigned agree to abide by the statements above.

Katherine N. Washington, Student

Dr. Jason Hans, Major Professor

Dr. Jason Hans, Director of Graduate Studies 
ROMANTIC ATTACHMENT AMONG YOUNG ADULTS: THE EFFECTS OF PARENTAL DIVORCE AND RESIDENTIAL INSTABILITY

\section{THESIS}

A thesis submitted in partial fulfillment of the requirements for the degree of Master of Science in the College of Family Sciences at the University of Kentucky

By

Katherine N. Washington

Lexington, Kentucky

Director: Jason Hans, Professor of Family Science

Lexington, Kentucky 2012

Copyright ( C Katherine Noelle Washington 2012 
ABSTRACT OF THESIS

\section{ROMANTIC ATTACHMENT AMONG YOUNG ADULTS: THE EFFECTS OF PARENTAL DIVORCE AND RESIDENTIAL INSTABILITY}

Using an attachment theory perspective, variation in adult romantic attachment style outcomes were examined according to childhood experiences of parental divorce and residential instability. The sample was comprised of 172 individuals in the young adulthood developmental stage that were recruited using snowball sampling via online social networking. Participants completed an online survey containing the 36-item Experiences in Close Relationships scale and 28 author-developed items. The majority of the sample reported stable and predictable living arrangements as children. Those whose parents had divorced reported higher levels of parental conflict during their childhood than those whose parents had never divorced or separated. There was no statistical difference on adult romantic attachment style score between individuals who experience parental divorce or separation and those who did not. Parental conflict and stability of residence patterns did not have a statistically significant impact on attachment avoidance or anxiety. For participants whose parents had divorced or separated, conflict, residential stability, and time with nonresidential parent statistically improved the predictive ability of attachment anxiety. Specifically, time with nonresidential parent moderated adult romantic attachment anxiety.

KEYWORDS: Adult romantic attachment, Attachment, Childhood experiences, Childhood residence patterns, Parental divorce, 
ROMANTIC ATTACHMENT AMONG YOUNG ADULTS: THE EFFECTS OF PARENTAL DIVORCE AND RESIDENTIAL INSTABILITY

\author{
By
}

Katherine N. Washington

Jason Hans, Ph.D.

Director of Thesis

Jason Hans, Ph.D.

Director of Graduate Studies

April 13, 2012 


\section{TABLE OF CONTENTS}

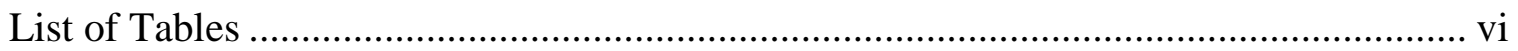

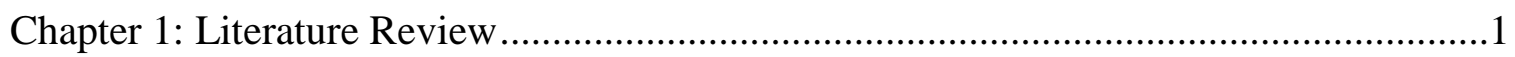

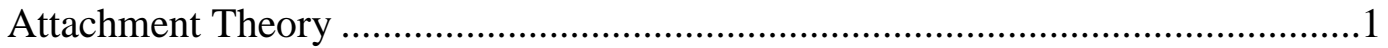

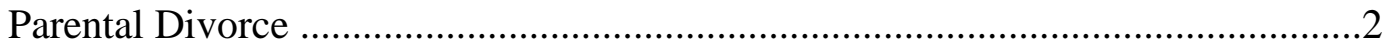

Adult Romantic Attachment ...................................................................6

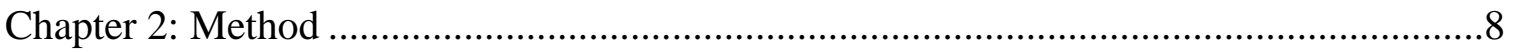

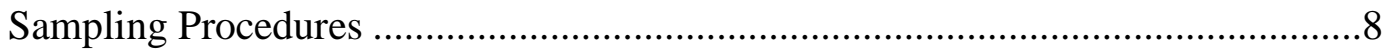

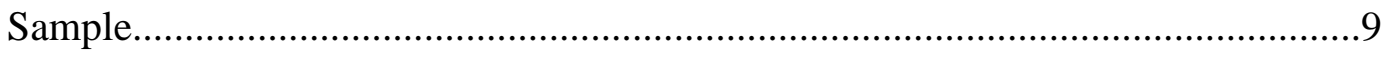

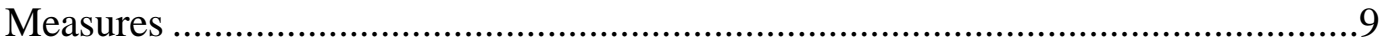

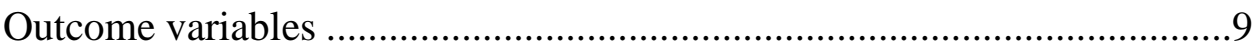

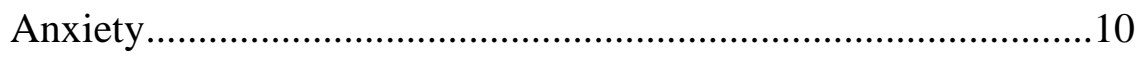

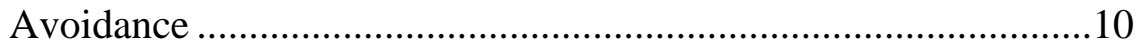

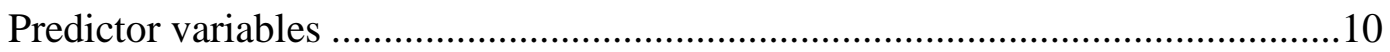

Parental divorce or separation.........................................................11

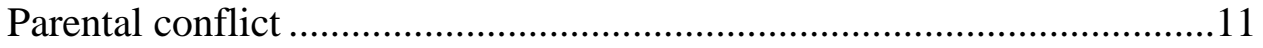

Stability of residential pattern ........................................................11

Mean days per week with nonresidential parents .................................11

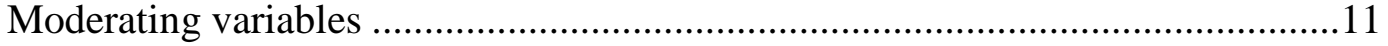

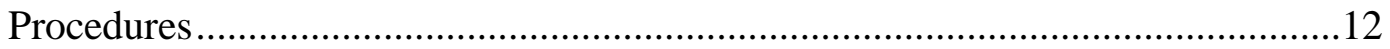

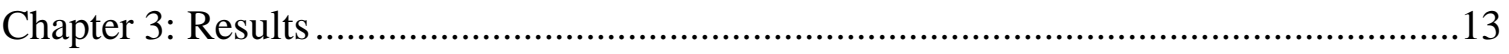

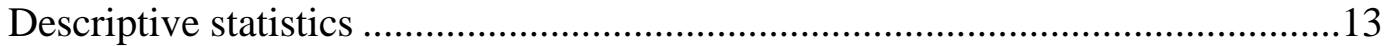

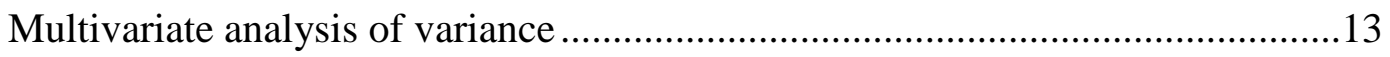

Hierarchical multiple regression ................................................................14

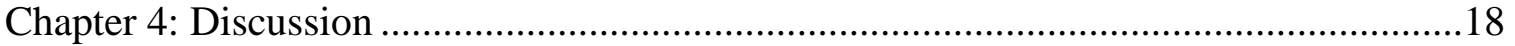

Parental separation or divorce and adult romantic attachment ...........................18

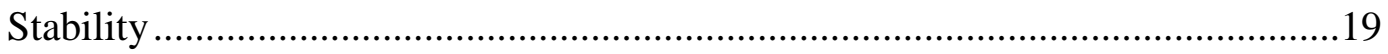

Time spent with nonresidential parent .............................................................19

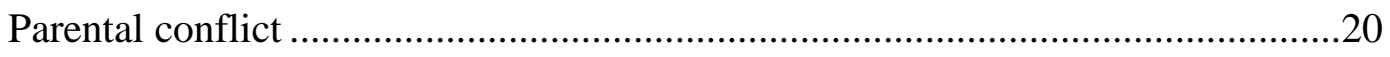

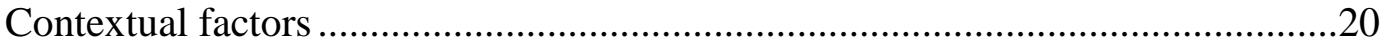

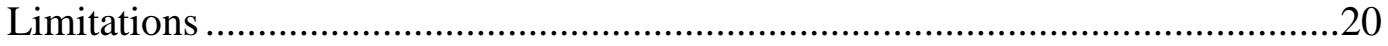




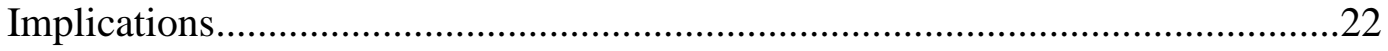

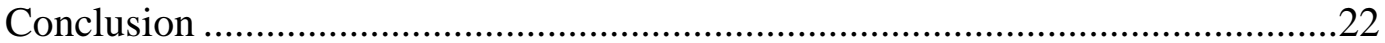

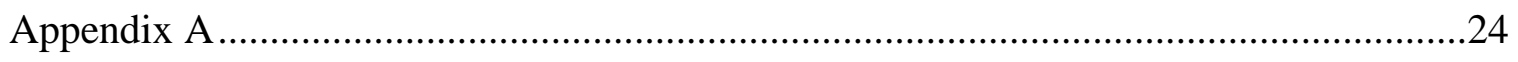

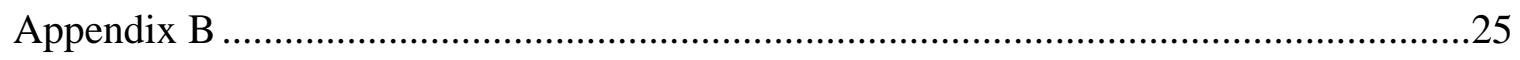

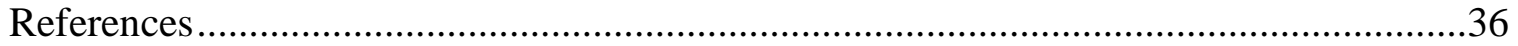

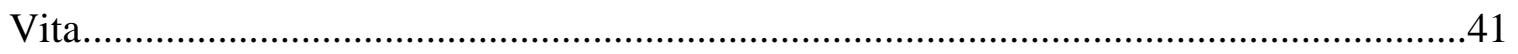




\section{LIST OF TABLES}

Table 3.1, Demographic characteristics of participants...............................................16

Table 3.2, Hierarchical multiple regression analysis summary for stability and conflict predictive anxiety and avoidance when controlling for gender .....................17

Table 3.3, Hierarchical multiple regression analysis summary for stability, conflict and time with nonresidential parent predicting anxiety and avoidance when controlling for genera and age at parental separation 


\section{Chapter 1}

\section{Literature Review}

Attachment literature indicates that childhood relationships set the foundation for relationships later in life; the way in which one interacts and forms close bonds in adulthood is influenced by his or her childhood relationship with a primary caregiver (Ainsworth, 1985; Bartholomew \& Horowitz, 1991; Bowlby 1980). Thus, childhood attachment experiences may provide a way to understand adult romantic relationships. For example, research has found links between attachment and adjustment to divorce in childhood (Faber \& Wittenborn, 2010). However, parental separation may affect attachment to a primary caregiver differently, and thereby be associated with varying levels of attachment-related outcomes, according to how the transition affects parenting patterns and living arrangements. In particular, relationships with primary caregivers may be disrupted, which may in turn have implications for how one bonds with romantic partners in adulthood. Therefore, the purpose of this study is to understand the relationship between residential patterns in childhood and adult romantic attachment. I begin by describing attachment theory, followed by a brief review of the literature on children's outcomes following parental divorce and the implications of parental divorce for romantic attachment in adulthood.

\section{Attachment Theory}

Attachment theory was originally developed in the 1960’s to describe infant-caregiver relationships, but has since evolved to include close relationships across the lifespan. Attachment theory describes emotional responses as well as behaviors and thought processes (Bowlby, 1969/1982; Crowell et al., 2009; Hazan \& Shaver, 1987). The theory posits that bonds 
are formed between children and their primary caregivers, and that caregiver responsiveness and attentiveness leads to secure attachment, while inconsistency and distance leads to insecure attachment (Bowlby). Bartholomew (1990) described infant attachment as "coherent patterns of behavior which indicate the quality of the attachment bond within a relationship” (p. 150). This can be observed when infants are separated and then reunited with their caregivers. Securely attached children seek out physical proximity with their caregivers, are easily comforted, and seem to respond positively upon reunion with their parents (Bartholomew). When caregivers provide a secure base, children are free to explore the unknown with the confidence that accompanies knowing that they have a safe haven, or a comfortable and trustworthy place of retreat to find peace and restoration (Feeney \& Monin, 2008). Insecurely attached children can be categorized as anxious-resistant or avoidant. Insecurely attached infants are difficult to comfort when distressed, less affected by separation from their caregivers than are more securely attached infants, do not seem to welcome reunions with caregivers, and some ignore their caregivers (Bartholomew). From these early experiences children organize how they view the world, how they perceive people who are close to them, and how they interact with their romantic partners later in life (Crowell et al.; Hazan \& Shaver; Werner-Wilson \& Davenport, 2003). Those who develop secure attachments tend to have low anxiety about close relationships and do not avoid closeness with others, whereas those who develop insecure attachments tend to avoid intimacy and experience discomfort when experiencing emotional closeness with others (Simpson \& Rholes, 1998).

\section{Parental Divorce}

Most studies of children's post-divorce experiences report some negative outcomes (Coleman \& Glenn 2010; Kushner, 2009). For example, children’s living arrangements have 
implications for educational success; children living in households with married, biological parents in the home tend to be better off than children in any other living arrangement (Teachman, 2008). Stability is also a predictor of children's outcomes; changes in residence, school, and household family structure negatively impact children’s outcomes following parental separation (Berger, Brown, Joung, Melli, \& Wimer, 2008; Coleman \& Glenn, 2010).

The quality of time that children spend with their nonresidential parents can vary greatly depending on the time of day, child-rated importance of activities shared, frequency of visits, and the closeness of the parent-child relationship. One study found that overnight stays were an indicator of parental involvement and relationship quality between an adolescent and parent, and that conflict between parents was inversely related to the frequency of overnight visits adolescents had with their nonresidential parents (Cashmore, Parkinson, \& Taylor, 2008). Cashmore and colleagues also reported that adolescents who saw their nonresidential parent more than once every other weekend had higher levels of closeness with that parent and rated the parent as more involved.

Children who spend more time with their nonresidential fathers tend to be more resilient after parental divorce (Faber \& Wittenborn, 2010; Kelly \& Emery, 2003), provided the resulting residential patterns are predictable and routine. Both children and adult children of divorce have reported that visitation arrangements were one of the biggest drawbacks to parental divorce (Hans \& Fine, 2002; Lambert, 2007). For example, one participant in Lambert’s study reported feeling like an "annoyance" to the nonresidential parent and another "never really [felt] settled in one spot” (p. 68).

Inconsistent time and access to the primary caregiver, such as what may happen following parental divorce, could negatively impact the formation of a secure base for the child 
(Feeney \& Monin, 2008). The impact that parental divorce has on a child's attachment formation depends on contextual circumstances, such as quality of parenting, visitation patterns, family income changes, and the child's age and cognitive ability (Feeney \& Monin). In general, however, children of divorce are more likely to become fearful and preoccupied (i.e., develop insecure attachments) compared to children who never experience parental divorce (Feeney \& Monin; Werner-Wilson \& Davenport, 2003).

The impact that divorce has on attachment may depend on the consistency between preand post-divorce residential patterns, especially with regard to the primary caregiver relationship. Regardless of any residential pattern changes, one or both parents may become more inwardly focused in an attempt to meet their own emotional needs during and after the separation process, which may be perceived as rejection by a child and consequently affect attachment bonds (Faber \& Wittenborn, 2010). Another threat to attachment bonds occurs when caregivers introduce romantic partners, remarry, and add stepchildren to the household (Faber \& Wittenborn).

If a child continues to live primarily with the primary caregiver following a parental divorce then the attachment bond may continue to develop on the same pre-divorce trajectory. Children who spend less time with the primary caregiver following parental divorce, perhaps due to joint physical custody, however, may experience more detrimental effects stemming from a parental divorce. Decreased interaction may be interpreted as abandonment, fostering anxiety and avoidant behaviors characteristic of insecure attachment (Faber \& Wittenborn, 2010). Another plausible outcome is that frequent contact with both parents following divorce could foster or maintain secure attachments with both caregivers; children in predictable joint custody arrangements seem to adjust to parental divorce better than children who do not have a stable visitation schedule (Bauserman, 2002; Faber \& Wittenborn). 
Some adults interviewed about their parents' divorce have reported generally positive childhood experiences associated with parental divorce, but the majority primarily associate negative experiences with parental divorce (Cartwright, 2006; Lambert, 2007). Among the drawbacks retrospectively reported to Cartwright and Lambert by adult children of divorce were low self-esteem, lack of trust in oneself and others, difficulty in romantic relationships, pessimism about the institution of marriage, instable living arrangements, sharing time on holidays, not having a good example of a stable relationship, persistent family conflict, financial strain, and the loss of important relationships. Perceived benefits experienced by some children of divorce included resiliency, independence, happiness, having a model of what not to do in their own relationships, and closer family relationships once marital conflict within the household ended.

Some children of divorce experience negative effects into young adulthood that have been associated with numerous implications for adult romantic relationships. For example, compared to adults whose parents remained married, adults who experienced parental divorce tend to hold more negative attitudes toward marriage (Cui \& Fincham, 2010), experience more difficulties in romantic relationships (Amato \& Sobelewski, 2001; Cartwright, 2006; Cui \& Fincham, 2010; Lambert, 2007), and are more likely to experience a divorce themselves (Amato \& DeBoer, 2001; Teachman, 2008). Parental divorce has also been associated with lower levels of confidence in one's own relationship skills, more instability when difficulty arises in a romantic relationship, and less desire for marriage coupled with more tolerance for divorce (Cartwright; Cui \& Fincham; Lambert). Many of these findings are likely interrelated, such as Cui and Fincham's finding that adult children of divorce exhibited "weaker commitment to their current romantic relationship, which was, in turn, linked to lower relationship quality” (p. 340), 
and that parental conflict styles were linked with young adults' conflict styles in romantic relationships.

Despite their family of origin experiences, most adult children of divorce view marriage as a life-long commitment (Cunningham \& Thornton, 2005). Some individuals report that experiencing their parents' divorce sensitized them to the potential consequences of an unsatisfying marriage, which in turn increased vigilance with regard to their own relationships in an attempt to avoid experiencing a divorce themselves (Cartwright, 2006).

\section{Adult Romantic Attachment}

Early life experiences have been theorized to impact attachment throughout the lifespan. Attachment theory applied to adult relationships focuses on romantic partners rather than caregivers. Childhood attachment experiences are believed to develop a view of self that, when coupled with a romantic partner's responses in adulthood, leads to the formation of a secure base or insecure attachment (Hazan \& Shaver, 1987; Rutter \& O’Connor, 1999; Simpson \& Rholes, 1998; Werner-Wilson \& Davenport, 2003). Adult attachments, specifically those with romantic partners, could therefore be impacted by parental divorce much earlier in the life course. Adult romantic attachment has four classifications according to how one views self and others: (a) secure: positive view of self and others; (b) preoccupied: negative view of self, positive view of others; (c) fearful/avoidant: negative view of both self and others; and (d) dismissing/avoidant: positive view of self, negative view of others.

This study examines the relationship between parental separation, residence patterns following separation, and adult romantic attachment. Specifically, the predictive ability of childhood experiences on avoidance and anxiety in adult romantic relationships will be examined. I hypothesized that avoidant and anxious adult romantic attachment styles are 
positively correlated with (a) parental divorce or separation and (b) perceived severity of parental conflict. I also predicted that avoidant and anxious adult romantic attachment styles are negatively correlated with (a) perceived stability of childhood residential patterns and (b) residential patterns that include time with both parents. The role, if any, that children's age at separation and gender play in these hypothesized relationships will also be explored. 


\section{Chapter 2}

\section{Method}

\section{Sampling Procedures}

Individuals in Craig and Dunn’s (2006) young adulthood developmental stage (18 to 40 years of age) were targeted for participation because one of the primary tasks of this developmental stage is to create and build intimate relationships and develop emotional intelligence. Craig and Dunn describe emotional intelligence as an overall development of selfawareness in relation to others as well as understanding the emotions of others and how to solve relationship challenges. Thus, negotiating adult romantic attachments is a key developmental task of young adults.

Participants were recruited through snowball sampling via online social networking. The use of social networking in the U.S. is increasing; 74\% of Americans use the internet (Rainie, 2010) and 69\% who use the internet have an account on a social networking site, up from 34\% of internet users in 2008 (Hampton, Goulet, Rainie \& Purcell, 2011), making social networking sites increasingly useful tools for research participant recruitment. Hampton et al. reported that the mean age of online social networkers is 38 , about $77 \%$ of all online social networkers are between the ages of 18 and 49 , and that $56 \%$ of social networking sites users are female. However, in general they found that social networking site users represent a wide range of ages, ethnicities, and educational backgrounds.

Facebook is the most frequently used online social networking website and that $52 \%$ of Facebook users access the website daily (Hampton et al., 2011). Given the ubiquity of Facebook, particularly among young adults, respondents were recruited using an open Facebook 
event. A recruitment email describing the research purpose was also distributed to potential respondents (see Appendix A). Electronic recruitment allowed the survey to be distributed to a large and diverse social network, and recipients were encouraged to forward the email or Facebook event invitation to their social networks. Professors of social science departments at major universities were also emailed and encouraged to forward the email.

\section{Sample}

The sample was comprised of 172 individuals (80.8\% female), ranging in age from 18 to $41(M=26.5, S D=3.9)$. The majority of the sample was either married (35.7\%), single (29.0\%), or in a committed relationship (22.6\%); fewer respondents classified themselves as casually dating (5\%), engaged (6.3\%), divorced (0.9\%), or widowed (0.5\%). The sample was primarily Caucasian (72.9\%), followed by Asian-American (2.7\%), African-American (1.8\%), Arab-American (0.9\%), Latin-American (0.9\%), Pacific Islander (0.9\%), and Native-American (0.5\%). About one-quarter (26.0\%) had completed an advanced college degree, an additional 17.9\% had completed some graduate education, 38.7\% had a 4-year college degree but had no graduate education, $11.0 \%$ had some college but not a degree, $4.0 \%$ had completed a 2-year college degree, and 1.7\% had a high school diploma but no college education. Forty-seven respondents (27.3\%, approximately $80 \%$ of which were female) indicated that their parents had separated or divorced before they were 18 years old.

\section{Measures}

Outcome variables. The Experiences in Close Relationships (ECR) scale (Brennan, Clark, \& Shaver, 1998) was created by first compiling all known self-report measures of adult romantic attachment, including unpublished conference submissions, then conducting a factor analysis of all of the items. Ultimately, 36 items with the highest absolute value correlations 
were retained, and those items loaded on two dimensions: avoidance and anxiety. The ECR has high internal consistency within each dimension—avoidance: Cronbach’s alpha $=.94$; anxiety: Cronbach's alpha $=.91$-and the two dimensions are virtually independent, $r=.11$. The items are one-sentence statements about how one generally experiences relationships, with seven-point Likert-type response options anchored by disagree strongly and agree strongly.

Anxiety. The anxiety dimension consists of 18 items with a subscale score range of 18 to 126 and correlates to other measures of anxiety, preoccupation with attachment, jealously, and fear of rejection. The statements that assess attachment anxiety include items such as "I worry about being abandoned," "I worry a lot about my relationships,” and "My desire to be very close sometimes scares people away.”

Avoidance. The avoidance dimension consists of 18 items with a score range of 18 to 126 and correlates with other measures of avoidance and discomfort with closeness. The statements that assess attachment avoidance include “I don’t feel comfortable opening up to romantic partners," "I find it difficult to allow myself to depend on romantic partners," and "I want to get close to my partner, but I keep pulling back.”

Predictor variables. Childhood experiences were queried using 28 author-developed items designed to garner information on respondents’ relationship status and history, demographic and background information, parental demographic and background information, and childhood residential patterns and experiences (see Appendix B). Respondents whose parents had separated or divorced were instructed to focus on the first two years following parental separation or divorce when responding to the childhood experiences items. For example all participants were asked about parental conflict, but children of divorce or separation were given further instruction to only consider the first two years after the divorce or separation. 
Parental divorce or separation. Participants were asked if their parents ever separated before they were 18 and in a separate question were asked if their parents ever divorced. Individuals who responded “yes” were then asked when their parents separated or divorced.

Parental conflict. Perceived parental conflict during childhood was measured with a retrospective item: "How would you describe the level of conflict your parents had regarding your care or discipline?” Response options ranged from little to no conflict to frequent and sever conflict on a 5-point scale.

Stability of residential pattern. Each participant was asked "How would you describe your residence patterns in your childhood? If your parents separated or divorced, think about the first two years after your parents separated.” Response options ranged from stable and predictable (1) to continually changing and unpredictable (5) on a 5-point scale.

Mean days per week with nonresidential parent. Participants whose parents had divorced or separated were presented with a series of questions about their childhood residential patterns with each parent. For example, "How many nights a week, on average, did you spend at your father's/mother's residence? For example, if you spent Friday and Saturday nights at your father's/mother's residence every other weekend, the you spent an average of one night per week."

Moderating variables. Age at parental divorce or separation, gender, and parental conflict were hypothesized to have moderating effects on the relationship between the predictor variables and the outcome variables. In other words, the relationship between the predictor and outcome variables was expected to differ according to these variables. Respondent age at parental separation or divorce, where applicable, was calculated using the reported date of parental separation or divorce and the respondent's date of birth. Those who did not know the 
date of separation or divorce were asked for their own age or grade in school when their parents separated or divorced. Parental conflict was used as a predictor variable when testing some hypotheses and as a moderating variable when testing other hypotheses.

\section{Procedures}

Respondents anonymously completed the online survey at their convenience. The survey was available on Qualtrics, a survey website, via a hyperlink on the Facebook event page and provided in the recruitment email. When participants clicked on the hyperlink they were directed to a webpage that described the survey and asked if they wished to continue. Those who continued were asked to provide basic demographic information and birthdate, but no additional identifying information was collected because individuals can be reluctant to respond honestly if they think that their responses can be traced back to them (Dillman, Smyth, \& Christian, 2009).

Respondents were first asked about their current romantic relationships, then the ECR was administered, followed by demographic information, and the survey concluded with childhood experiences. Most participants completed the survey in about 10-15 minutes. Data collection lasted for four months in 2011. 


\section{Chapter 3}

\section{Results}

\section{Descriptive Statistics}

Table 3.1 provides an overview of participant responses to the independent variables. The majority of the sample (73\%) reported that their living arrangements during childhood were stable and predictable; 3\% (all with divorced or separated parents except one) reported that their living arrangements were continually changing and unpredictable. Those whose parents had divorced $(M=2.95 ; S D=1.34)$ reported higher levels of conflict than those whose parents had not divorced $(M=1.81 ; S D=0.97)$, and the magnitude of the difference was large, $t(52)=4.98$, $p<.001, r^{2}=.32$. Respondent age at parental divorce varied a great deal $(M=7.86, S D=5.18)$ and those whose parents divorced reported spending about 1 day $(M=0.97, S D=1.09)$ per week with their nonresidential parents in the two years following divorce.

\section{Multivariate Analysis of Variance}

A multivariate analysis of variance (MANOVA) was performed to assess the relationship between parental divorce or separation in childhood and avoidant and anxious romantic attachment styles in adulthood. Normality, linearity, univariate and multivariate outliers, homogeneity of variances matrices, and multicollinearity were tested and no violations of MANOVA assumptions were found. There was not a statistical difference or effect on avoidant or anxious romantic attachment style scores between the individuals who experienced parental divorce or separation and those who did not, $F(2,168)=.11, p=.89$; Wilks’ Lambda = .99; partial eta squared $<.00$. 


\section{Hierarchical Multiple Regression}

Hierarchical multiple regression was used to test adult romantic attachment style outcomes according to (a) childhood residential patterns, (b) childhood residential stability, and (c) severity of parental conflict. The moderating roles of contextual variables (gender and age) at parental separation were also assessed. Four different hierarchical multiple regressions were performed to examine contextual variables (gender and age at parental separation) and asses the two outcome variables (anxiety and avoidance) separately. Anxiety and avoidance were first analyzed with the entire sample and then only with individuals who experienced parental divorce or separation to compare the results across groups. The data did not violate the regression assumptions of normality, linearity, multicollinearity, and homoscedasticity.

The first two hierarchical multiple regression models examined the effects that perceived severity of parental conflict and stability of residence patterns had on avoidant and anxious romantic attachment style scores within the entire sample while controlling for gender (see Table 3.2). Neither model was statistically significant; the models accounted for $3 \%$ of the variance in anxiety and $0.9 \%$ of the variance in avoidance, indicating that the effects were too small to be detected.

The second two hierarchical multiple regressions focused on respondents whose parents had divorced or separated and examined the predictive ability of conflict, residential stability, and time with nonresidential parent on attachment anxiety and avoidance while controlling for gender and age at parental separation (see Table 3.3). Conflict, residential stability, and time with nonresidential parent statistically improved the predictive ability of the anxiety model after controlling for gender and age at parental separation $\left(R^{2}\right.$ change $=.27, F$ change $(3,28)=3.69, p$ $=.023$ ); the full anxiety model explained $30.7 \%$ of the variance in anxiety. Time with 
nonresidential parent was the only statistically significant variable $(\beta=-.645, p=.005)$; continuing to spend time with both parents moderated attachment anxiety. 
Table 3.1

Demographic Characteristics of Participants $(\mathrm{N}=172)$

\begin{tabular}{|c|c|c|c|c|c|c|}
\hline \multirow[b]{2}{*}{ Characteristic } & \multicolumn{2}{|c|}{$\begin{array}{c}\text { Parents } \\
\text { Separated/Divorced }\end{array}$} & \multicolumn{2}{|c|}{$\begin{array}{c}\text { Parents Not } \\
\text { Separated/Divorced }\end{array}$} & \multicolumn{2}{|c|}{ Total } \\
\hline & $n$ & $\%$ & $n$ & $\%$ & $n$ & $\%$ \\
\hline \multicolumn{7}{|l|}{ Gender } \\
\hline Male & 8 & 20 & 26 & 20 & 34 & 20 \\
\hline Female & 33 & 81 & 105 & 80 & 139 & 80 \\
\hline \multicolumn{7}{|l|}{ Relationship Status } \\
\hline Single & 6 & 15 & 36 & 28 & 64 & 29 \\
\hline Casually dating & 1 & 3 & 9 & 7 & 11 & 5 \\
\hline Committed relationship & 14 & 34 & 30 & 23 & 50 & 23 \\
\hline Engaged & 4 & 10 & 9 & 7 & 14 & 6 \\
\hline Married & 15 & 37 & 47 & 36 & 79 & 36 \\
\hline Divorced & 1 & 2 & 0 & 0 & 2 & 1 \\
\hline \multicolumn{7}{|l|}{ Ethnicity (select all that apply) } \\
\hline Caucasian & 41 & 98 & 120 & 89 & 161 & 73 \\
\hline African-American & 0 & 0 & 3 & 2 & 4 & 2 \\
\hline Arab-American & 0 & 0 & 2 & 2 & 2 & 1 \\
\hline Asian-American & 1 & 3 & 5 & 4 & 6 & 3 \\
\hline Latin-American & 0 & 0 & 2 & 2 & 2 & 1 \\
\hline Native-American & 0 & 0 & 1 & 1 & 1 & 1 \\
\hline Pacific Islander & 0 & 0 & 2 & 1 & 2 & 1 \\
\hline \multicolumn{7}{|l|}{ Education completed } \\
\hline High school diploma/GED & 2 & 5 & 1 & 1 & 3 & 2 \\
\hline Some college & 5 & 12 & 14 & 11 & 19 & 11 \\
\hline Associates degree & 0 & 0 & 7 & 5 & 7 & 4 \\
\hline Bachelors degree & 14 & 34 & 53 & 41 & 67 & 39 \\
\hline Some graduate school & 8 & 20 & 23 & 18 & 31 & 18 \\
\hline Masters degree & 9 & 22 & 20 & 15 & 30 & 17 \\
\hline Doctoral degree & 2 & 5 & 13 & 10 & 15 & 9 \\
\hline Other & 1 & 2 & 0 & 0 & 1 & 1 \\
\hline
\end{tabular}


Table 3.2

Hierarchical Multiple Regression Analysis Summary for Stability and Conflict Predicting Anxiety and Avoidance when Controlling for Gender

\begin{tabular}{|c|c|c|c|c|c|c|c|c|c|c|}
\hline \multirow[b]{2}{*}{ Step and predictor variable } & \multicolumn{5}{|c|}{ Anxiety } & \multicolumn{5}{|c|}{ Avoidance } \\
\hline & $R^{2}$ & $\Delta R^{2}$ & $B$ & $S E B$ & $\beta$ & $R^{2}$ & $\Delta R^{2}$ & $B$ & $S E B$ & $\beta$ \\
\hline Step 1 & .03 & $.03^{*}$ & & & & .00 & -.00 & -.2 .56 & 3.97 & -.05 \\
\hline Gender $(n=173)$ & & & 8.21 & 3.97 & $.17^{*}$ & & & & & \\
\hline Step 2 & .03 & .00 & & & & .01 & -.01 & & & \\
\hline Conflict $(n=169)$ & & & .09 & 1.54 & .01 & & & -0.73 & 1.54 & -.04 \\
\hline Stability $(n=154)$ & & & 1.11 & 1.76 & .06 & & & 1.75 & 1.75 & .09 \\
\hline
\end{tabular}

Table 3.3

Hierarchical Multiple Regression Analysis Summary for Stability, Conflict, and Time with Nonresidential Parent Predicting Anxiety and Avoidance when Controlling for Gender and Age at Parental Separation

\begin{tabular}{|c|c|c|c|c|c|c|c|c|c|c|}
\hline \multirow[b]{2}{*}{ Step and predictor variable } & \multicolumn{5}{|c|}{ Anxiety } & \multicolumn{5}{|c|}{ Avoidance } \\
\hline & $R^{2}$ & $\Delta R^{2}$ & $B$ & SE B & $\beta$ & $R^{2}$ & $\Delta R^{2}$ & $B$ & $S E B$ & $\beta$ \\
\hline Step 1 & .03 & .03 & & & & .00 & -.06 & & & \\
\hline Gender $(n=47)$ & & & -2.90 & 9.14 & -.06 & & & 0.48 & 9.20 & .01 \\
\hline $\begin{array}{l}\text { Age at Parental } \\
\text { Separation/Divorce }(n=42)\end{array}$ & & & 0.63 & 0.64 & .16 & & & 0.17 & 0.71 & .04 \\
\hline Step 2 & .31 & $.27 *$ & & & & .00 & -.06 & & & \\
\hline Conflict $(n=46)$ & & & 5.99 & 2.96 & .41 & .11 & -.05 & 4.52 & 3.37 & .31 \\
\hline Stability $(n=46)$ & & & 3.70 & 2.84 & .25 & & & 2.49 & 3.23 & .17 \\
\hline $\begin{array}{l}\text { Time with Nonresidential } \\
\text { Parent }(n=39)\end{array}$ & & & -12.00 & 3.95 & $-.65^{*}$ & & & -5.29 & 4.49 & -.28 \\
\hline
\end{tabular}

Note. Only respondents whose parents had divorced or separated were included in analysis.

$* p<.05$ 


\section{Chapter 4}

\section{Discussion}

Parental separation may impact a child's attachment bond with a caregiver and in turn have lasting effects on adult romantic attachment. Thus, the purpose of this study was to understand the relationship between childhood residency patterns associated with parental divorce and adult romantic attachment.

\section{Parental Separation or Divorce and Adult Romantic Attachment}

Individuals who had experienced parental divorce or separation were compared with those who had not to ascertain whether there was a difference in their adult romantic attachment. I hypothesized that parental divorce or separation in childhood would negatively impact adult romantic attachment. Specifically, adult children of divorce have reported difficulty in their romantic relationships and fear of relationships that would likely appear as attachment anxiety or avoidance (Amato \& Sobelewski, 2001; Cartwright, 2006; Cui \& Fincham, 2010; Lambert, 2007). However, the hypothesized relationship between parental divorce or separation and adult romantic attachment was not supported by these data.

Aside from the limitations of this sample, as described below, there are several possible explanations for this finding. Children with multiple attachment bonds in childhood (e.g., nonparental adults, siblings), or who are not bonded with the nonresident parent before separation (Cassidy, 2008), may not be affected in a lasting way by residential separation from the nonresidential parent. Also, the experience of divorce is not homogeneous; functional family dynamics after separation can shield children from many of the negative effects of divorce (Feeney \& Monin, 2008). This was the impetus for examining the hypotheses focused on 
experiences associated with residential stability, time spent with the nonresidential parent, and parental conflict following parental divorce.

\section{Stability}

Residential stability in childhood, which was measured as a single fixed-response item, did not predict adult romantic attachment. Response frequencies were highly concentrated at the "stable” end of the continuum, which may indicate that people tend to perceive what they are accustom to as stable, even if that meant going back and forth between two homes or changing geographic locations. Alternatively, any period of disruption that may have occurred could have been too brief to justify characterizing the two-year period following parental separation or divorce as instable.

\section{Time Spent with Nonresidential Parent}

Time spent with a nonresidential parent following parental divorce or separation was statistically related to anxiety. Individuals who score high on the ECR scale's anxiety dimension identify with statements such as "I worry about being abandoned," “I worry about being alone,” “I resent when my partner spends time away from me,” and "I get frustrated if romantic partners are not available when I need them” (Brennan, Clark, \& Shaver, 1998). Not having access to a parent after parental separation could lead to feelings of abandonment and insecurity that diminishes one’s “availability, accessibility, and sensitive responsiveness” into adulthood (Feeney \& Monin, 2008, p. 943). This finding supports the school of thought that a child's primary attachment figure is not necessarily a single person; both parents or multiple meaningful individuals in an infant's life can be attachment figures (Howes \& Spieker, 2008). Moreover, in most cases the nonresidential parent in these data was the father, which supports the idea that the primary attachment need not be a maternal figure (Bretherton, 2010; Howes \& Spieker). 


\section{Parental Conflict}

Parental conflict has been a consistent predictor of children's outcomes in the divorce literature (Amato, 2010). The single-item measurement, retrospective account, or focus exclusively on conflict over one's care or discipline may account for the low predictive power of parental conflict in these models. However, it may also be that parental conflict in childhood does not directly affect adult romantic attachment. Potential mediating factors that could not be assessed with these data include type of conflict (verbal or physical), duration of conflict across time, and the potential resolution of conflict years after separation or divorce.

\section{Contextual Factors}

Contextual factors_-gender, age at parental separation — were controlled for in the analyses; their ability to predict anxiety and avoidance was tested before any other variables were examined. One test found a statistical difference in attachment anxiety according to gender — females were more likely than males to have an anxious attachment style—but the effect size suggests that this difference was not particularly meaningful. Regardless, these data do not provide a comprehensive relationship history to assess the reason for this finding. What can be stated is that multiple relationship and primary attachment experiences likely contribute to one's level of attachment anxiety in adulthood.

\section{Limitations}

Three important drawbacks to this study likely diminished the power to clearly discern the relationship between childhood experiences and adult romantic attachment. Specifically, childhood experiences were reported retrospectively, experiences were measured using single survey items, and the sample composition was not ideal for this study. 
Retrospectively reporting childhood experiences such as level of parental conflict, time spent with each parent following divorce or separation, and residential stability patterns can be problematic. Amodeo and Griffin (2009) found siblings had 53-62\% agreement when independently providing retrospective reports of their childhood family environment, and Sher and Descutner (1986) found that sibling agreement was higher for observable behaviors such as "father sought help for his drinking” than for subjective inferences such as "father felt guilty about drinking.” Respondents' current relationships with their parents as well as the numerous interactions since parental separation could alter perceptions and recollections of childhood experiences (Brewin, Andres, \& Gotlib, 1993). This does not discount the value of retrospective reports, but suggests that capturing information at the time of the divorce itself and following up with the participants as adults would likely produce more reliable results than those reported here.

Another way to at least partially address validity and reliability concerns with regard to retrospective data, in the absence of prospective data, would have been to not rely on individual responses using single survey items to measure the key variables. Multi-item instruments designed to measure conflict or household stability, for example, may have provided more reliable estimates of childhood experiences. In addition, had the data been triangulated, such as by encouraging respondents to have their siblings complete the survey too, then the validity of these respondents' reports could have been assessed, and the results of that assessment may have enhanced the credibility of these retrospective data.

The need for more detailed answers arose while speculating on the implications of constructs such as stability. Without the ability to ask participants follow-up questions or for their perception of a particular item (e.g., Do you consider living arrangements to be the house 
you lived in or the make up of the members in your household?) the question was left open to interpretation. Qualitative follow up may have enhanced the results.

Having participants who experienced a wide variety of custody arrangements and residential patterns would have been ideal for this study, but the number of respondents that had experienced parental divorce, and especially joint physical custody, was small. This impeded the power of the statistical tests and provided a rather narrow view of the population that was to be studied. The predominance of females and highly educated respondents in the sample also limits the generalizability of the findings.

\section{Implications}

The sample did have limitations, however the findings still have implications for therapeutic work with families, divorce mediators, and family educators. Individuals working with divorcing parents and children need to be cognoscente of the impact their decisions about custody have on the development of the child. This study's findings suggest that the formation and maintenance of attachment bonds requires that the child continue to have access to both parents. It becomes imperative that the parents work together to reduce the conflict in their relationship and create a stable and predictable visitation pattern for the child. Professionals and families alike need to make themselves aware of the potential for long-term outcomes due to their decisions early in a child's life.

\section{Conclusion}

Spending time with both parents following parental divorce can help children to maintain their attachment relationships, and may have implications for adult romantic attachment. The findings of this study were largely inconclusive-further investigation is needed to overcome the limitations of this study—but the relationship between residential patterns following parental 
separation or divorce and children's long-term outcomes is an important direction for future research. Effects may generally be small, but the cumulative outcome of numerous small effects can have a large impact on children of divorce as they develop and transition into adulthood. 


\section{Appendix A}

\section{Informed Consent}

All participants must be between the ages of 18-40.

You are invited to take part in a research study about childhood experiences and present feelings about close relationships. More specifically, the survey will ask questions about your childhood residential patterns and your experience with your parents. You will also be presented with questions about how you generally feel in close relationships as an adult.

The person in charge of this study Katie Terrana of University of Kentucky Department of Family Studies. She is being guided in this research by Jason Hans, Ph.D., CFLE.

Although you will not get personal benefit from taking part in this research study, your responses may help us understand more about how the experiences we have in childhood impact the relationships we have as adults. We hope to receive completed questionnaires from about 100 people, so your answers are important to us. Of course, you have a choice about whether or not to complete the survey, but if you do participate, you may skip any questions or discontinue at any time.

The survey will take about 20 minutes to complete.

There are no known risks to participating in this study. While we do not anticipate this, it is possible that answering the questions may be uncomfortable for you. You are not required to answer any questions and you may quit the survey at any time by closing your web browser window.

Your responses to the survey are anonymous, which means the research team will not know that any information you provided came from you, nor even whether you participated in the study. Therefore, no respondent names will appear or be used on research documents or be used in presentations or publications.

If you have questions about the study, please feel free to ask; my contact information is given below. If you have complaints, suggestions, or questions about your rights as a research volunteer, contact the staff in the University of Kentucky Office of Research Integrity at 859257-9428 or toll-free at 1-866-400-9428.

Thank you in advance for your assistance with this important project.

Sincerely,

Katie Terrana

Family Studies Department, University of Kentucky

(859)257-7750

katie.terrana@uky.edu 


\section{Appendix B}

\section{Survey}

I am at least 18 years old, I have read and understood the above disclosure, and I wish to begin the survey.

$1=$ Yes

$2=$ No

If No Is Selected, Then Skip To End of Survey

\section{Relationship Status and History}

Q1. How would you describe your current relationship status?

$1=$ Single

2 = Casually Dating

3 = Committed Relationship

$4=$ Engaged

5 = Married

$6=$ Divorced

$7=$ Widowed

Q2. How many committed relationship have you been in?

$$
\begin{aligned}
& 1=0 \\
& 1=2 \\
& 3=4 \\
& 4=5 \\
& 5=6 \\
& 6=7 \\
& 7=8 \\
& 8=9 \\
& 9=10 \\
& 10=11 \\
& 11=12 \\
& 12=13 \\
& 13=14 \\
& 14=15 \\
& 15=16 \\
& 16=17 \\
& 17=18 \\
& 18=19 \\
& 19=20 \\
& 20=21
\end{aligned}
$$

\section{Experiences in Close Relationships Scale}


Q3-Q38. The following statements concern how you feel in romantic relationships. We are interested in how you generally experience relationships, not just what is happening in a current relationship. Respond to each statement by indicating how much you agree or disagree with it.

\begin{tabular}{|c|c|c|c|c|c|c|c|}
\hline & $\begin{array}{c}\text { Disagree } \\
\text { Strongly } \\
1\end{array}$ & 2 & 3 & $\begin{array}{l}\text { Neutral/ } \\
\text { Mixed } \\
4\end{array}$ & 5 & 6 & $\begin{array}{c}\text { Agree } \\
\text { Strongly } \\
7\end{array}$ \\
\hline $\begin{array}{l}\text { 3. I prefer not to show a } \\
\text { partner how I feel deep } \\
\text { down. }\end{array}$ & 1 & 2 & 3 & 4 & 5 & 6 & 7 \\
\hline $\begin{array}{l}\text { 4. I worry about being } \\
\text { abandoned. }\end{array}$ & 1 & 2 & 3 & 4 & 5 & 6 & 7 \\
\hline $\begin{array}{l}5 . \text { I am very comfortable } \\
\text { being close to romantic } \\
\text { partners. }\end{array}$ & 1 & 2 & 3 & 4 & 5 & 6 & 7 \\
\hline $\begin{array}{l}5 \text {. I worry a lot about my } \\
\text { relationships. }\end{array}$ & 1 & 2 & 3 & 4 & 5 & 6 & 7 \\
\hline $\begin{array}{l}\text { 7.Just when my partner } \\
\text { starts to get close to me I } \\
\text { find myself pulling } \\
\text { away. }\end{array}$ & 1 & 2 & 3 & 4 & 5 & 6 & 7 \\
\hline $\begin{array}{l}\text { 8. I worry that romantic } \\
\text { partners won't care } \\
\text { about me as much as I } \\
\text { care about them. }\end{array}$ & 1 & 2 & 3 & 4 & 5 & 6 & 7 \\
\hline $\begin{array}{l}\text { 9. I get uncomfortable } \\
\text { when a romantic partner } \\
\text { wants to be very close. }\end{array}$ & 1 & 2 & 3 & 4 & 5 & 6 & 7 \\
\hline $\begin{array}{l}\text { 10.I worry a fair amount } \\
\text { about losing my partner. }\end{array}$ & 1 & 2 & 3 & 4 & 5 & 6 & 7 \\
\hline $\begin{array}{l}\text { 11. don't feel } \\
\text { comfortable opening up } \\
\text { to romantic partners. }\end{array}$ & 1 & 2 & 3 & 4 & 5 & 6 & 7 \\
\hline $\begin{array}{l}\text { 12. I often wish that my } \\
\text { partner's feelings for me } \\
\text { were as strong as my } \\
\text { feelings for him/her. }\end{array}$ & 1 & 2 & 3 & 4 & 5 & 6 & 7 \\
\hline $\begin{array}{l}\text { 13. I want to get close to } \\
\text { my partner, but I keep } \\
\text { pulling back. }\end{array}$ & 1 & 2 & 3 & 4 & 5 & 6 & 7 \\
\hline $\begin{array}{l}\text { 14. I often want to merge } \\
\text { completely with } \\
\text { romantic partners, and } \\
\text { this sometimes scares } \\
\text { them away. }\end{array}$ & 1 & 2 & 3 & 4 & 5 & 6 & 7 \\
\hline $\begin{array}{l}\text { 15. I am nervous when } \\
\text { partners get too close to }\end{array}$ & 1 & 2 & 3 & 4 & 5 & 6 & 7 \\
\hline
\end{tabular}




\begin{tabular}{|c|c|c|c|c|c|c|c|}
\hline me. & & & & & & & \\
\hline $\begin{array}{l}\text { 16. I worry about being } \\
\text { alone. }\end{array}$ & 1 & 2 & 3 & 4 & 5 & 6 & 7 \\
\hline $\begin{array}{l}\text { 17. I feel comfortable } \\
\text { sharing my private } \\
\text { thoughts and feelings } \\
\text { with my partner. }\end{array}$ & 1 & 2 & 3 & 4 & 5 & 6 & 7 \\
\hline $\begin{array}{l}\text { 18. My desire to be very } \\
\text { close sometimes scares } \\
\text { people away. (16) }\end{array}$ & 1 & 2 & 3 & 4 & 5 & 6 & 7 \\
\hline $\begin{array}{l}\text { 19. I try to avoid getting } \\
\text { too close to my partner. }\end{array}$ & 1 & 2 & 3 & 4 & 5 & 6 & 7 \\
\hline $\begin{array}{l}20 \text {. I need a lot of } \\
\text { reassurance that I am } \\
\text { loved by my partner. }\end{array}$ & 1 & 2 & 3 & 4 & 5 & 6 & 7 \\
\hline $\begin{array}{l}21 . \text { I find it relatively } \\
\text { easy to get close to my } \\
\text { partner. }\end{array}$ & 1 & 2 & 3 & 4 & 5 & 6 & 7 \\
\hline $\begin{array}{l}\text { 22. Sometimes I feel that } \\
\text { I force my partners to } \\
\text { show more feeling, more } \\
\text { commitment. }\end{array}$ & 1 & 2 & 3 & 4 & 5 & 6 & 7 \\
\hline $\begin{array}{l}\text { 23. I find it difficult to } \\
\text { allow myself to depend } \\
\text { on romantic partners. }\end{array}$ & 1 & 2 & 3 & 4 & 5 & 6 & 7 \\
\hline $\begin{array}{l}\text { 24. I do not often worry } \\
\text { about being abandoned. }\end{array}$ & 1 & 2 & 3 & 4 & 5 & 6 & 7 \\
\hline $\begin{array}{l}25 . \text { I prefer not to be too } \\
\text { close to romantic } \\
\text { partners. }\end{array}$ & 1 & 2 & 3 & 4 & 5 & 6 & 7 \\
\hline $\begin{array}{l}\text { 26. If I can't get my } \\
\text { partner to show interest } \\
\text { in me, I get upset or } \\
\text { angry. }\end{array}$ & 1 & 2 & 3 & 4 & 5 & 6 & 7 \\
\hline $\begin{array}{l}\text { 27. I tell my partner just } \\
\text { about everything. }\end{array}$ & 1 & 2 & 3 & 4 & 5 & 6 & 7 \\
\hline $\begin{array}{l}\text { 28. I find that my } \\
\text { partner(s) don't want to } \\
\text { get as close as I would } \\
\text { like. }\end{array}$ & 1 & 2 & 3 & 4 & 5 & 6 & 7 \\
\hline $\begin{array}{l}\text { 29. I usually discuss my } \\
\text { problems and concerns } \\
\text { with my partner. }\end{array}$ & 1 & 2 & 3 & 4 & 5 & 6 & 7 \\
\hline 30. When I'm not & 1 & 2 & 3 & 4 & 5 & 6 & 7 \\
\hline
\end{tabular}




\begin{tabular}{|c|c|c|c|c|c|c|c|}
\hline $\begin{array}{l}\text { involved in a } \\
\text { relationship, I feel } \\
\text { somewhat anxious and } \\
\text { insecure. }\end{array}$ & & & & & & & \\
\hline $\begin{array}{l}\text { 31. I feel comfortable } \\
\text { depending on romantic } \\
\text { partners. }\end{array}$ & 1 & 2 & 3 & 4 & 5 & 6 & 7 \\
\hline $\begin{array}{l}\text { 32. I get frustrated when } \\
\text { my partner is not around } \\
\text { as much as I would like. }\end{array}$ & 1 & 2 & 3 & 4 & 5 & 6 & 7 \\
\hline $\begin{array}{l}\text { 33. I don't mind asking } \\
\text { romantic partners for } \\
\text { comfort, advice, or help. }\end{array}$ & 1 & 2 & 3 & 4 & 5 & 6 & 7 \\
\hline $\begin{array}{l}\text { 34.I get frustrated if } \\
\text { romantic partners are not } \\
\text { available when I need } \\
\text { them. }\end{array}$ & 1 & 2 & 3 & 4 & 5 & 6 & 7 \\
\hline $\begin{array}{l}\text { 35. It helps to turn to my } \\
\text { romantic partner in times } \\
\text { of need. }\end{array}$ & 1 & 2 & 3 & 4 & 5 & 6 & 7 \\
\hline $\begin{array}{l}\text { 36. When romantic } \\
\text { partners disapprove of } \\
\text { me, I feel really bad } \\
\text { about myself. }\end{array}$ & 1 & 2 & 3 & 4 & 5 & 6 & 7 \\
\hline $\begin{array}{l}\text { 37. I turn to my partner } \\
\text { for many things, } \\
\text { including comfort and } \\
\text { reassurance. }\end{array}$ & 1 & 2 & 3 & 4 & 5 & 6 & 7 \\
\hline $\begin{array}{l}\text { 38. I resent it when my } \\
\text { partner spends time } \\
\text { away from me. }\end{array}$ & 1 & 2 & 3 & 4 & 5 & 6 & 7 \\
\hline
\end{tabular}

Q39 Demographic and Background Information. Please choose the most applicable answer. Gender

$$
\begin{aligned}
& 1=\text { Male } \\
& 2=\text { Female }
\end{aligned}
$$

Q43 Date of Birth (Year)

Q46 Date of Birth (Day and Month)

[drop down selection of day, then selection of month]

Q41 Ethnicity (please select ALL that apply)

$$
\begin{aligned}
& 1=\text { Caucasian } \\
& 2=\text { African-American } \\
& 3=\text { Arab-American }
\end{aligned}
$$




$$
\begin{aligned}
& 4=\text { Asian-American } \\
& 5=\text { Latin-American } \\
& 6=\text { Native-American } \\
& 7=\text { Pacific Islander } \\
& 8=\text { Other- please specify }
\end{aligned}
$$

Q42 Education Completed

$$
\begin{aligned}
& 1=\text { Less than high school } \\
& 2=\text { High School Diploma/GED } \\
& 3=\text { Some College } \\
& 4=\text { Associates Degree } \\
& 5=\text { Bachelors Degree } \\
& 6=\text { Some Graduate School } \\
& 7=\text { Masters Degree } \\
& 8=\text { Doctoral Degree } \\
& 9=\text { Other- please specify }
\end{aligned}
$$

Q43 Demographic and Background Information about your Father.

When responding to questions about your father please think of your biological father (or, if you were adopted, your adoptive father).

Father's Date of Birth (Year)

[drop down selection]

Q49 Father's Date of Birth (Month)

[drop down 1-12]

Q44 Father's Education Completed

$$
\begin{aligned}
& 1=\text { Less than high school } \\
& 2=\text { High School Diploma/GED } \\
& 3=\text { Some College } \\
& 4=\text { Associates Degree } \\
& 5=\text { Bachelors Degree } \\
& 6=\text { Some Graduate School } \\
& 7=\text { Masters Degree } \\
& 8=\text { Doctoral Degree } \\
& 9=\text { Other- please specify } \\
& 10=\text { Unknown }(10)
\end{aligned}
$$

Q50 Demographic and Background Information about your Mother. When responding to questions about your mother please think of your biological father (or, if you were adopted, your adoptive mother).

Mother's Date of Birth (Year)

[drop down selection] 
Q51 Mother's Date of Birth (Month)

[drop down 1-12]

Q46 Mother's Education Completed

$1=$ Less than high school

2 = High School Diploma/GED

$3=$ Some College

$4=$ Associates Degree

5 = Bachelors Degree

6 = Some Graduate School

7 = Masters Degree

8 = Doctoral Degree

$9=$ Other- please specify

$10=$ Unknown

Q47 Childhood Experiences

For the questions below please consider your experiences before the age of 18 . When responding to questions about your parents please think of your biological parents (or if you were adopted, your adoptive parents).

Were your parents ever married?

$$
\begin{aligned}
& 1=\text { Yes } \\
& 2=\text { No }
\end{aligned}
$$

Q48 Were your parents ever separated before you were 18?

$$
\begin{aligned}
& 1=\text { Yes } \\
& 2=\text { No }
\end{aligned}
$$

Answer: If "Were your parents ever separated before you were 18?" Yes is selected

Q49a How many times did your parents separate before you were 18?

[drop down 1-21 with a 21 or more option]

Answer: If "Were your parents ever separated before you were 18?" Yes is selected

Q49b When did your parents first separate? (MM/YYYY)

(MM/YYYY)

$2=$ Not sure

Answer: If “Were your parents ever separated before you were 18?” Yes is selected

Q49c How long was the separation? (include approximate number of months AND years)

Months - fill in number below

Years - fill in number below

Q50 Did your parents ever divorce?

$$
1=\text { Yes }
$$




$$
2=\mathrm{No}
$$

Answer: If "When did your parents divorce?” Not sure is selected.

Q50a When did your parents divorce?

(MM/YYYY)

$2=$ Not sure

Answer: If “When did your parents divorce?” Not sure is selected.

Q50aa How old were you when your parents divorced?

Answer: If "When did your parents divorce?” Not sure is selected.

Q50ab What grade were you in when your parents divorced?

$$
\begin{aligned}
& 1=\text { Kindergarten } \\
& 2=\text { First Grade } \\
& 3=\text { Second Grade } \\
& 4=\text { Third Grade } \\
& 5=\text { Fourth Grade } \\
& 6=\text { Fifth Grade } \\
& 7=\text { Sixth Grade } \\
& 8=\text { Seventh Grade } \\
& 9=\text { Eighth Grade } \\
& 10=\text { Ninth Grade } \\
& 11=\text { Tenth Grade } \\
& 12=\text { Eleventh Grade } \\
& 13=\text { Twelfth Grade } \\
& 14=\text { After High School } \\
& 15=\text { Freshman Year of College } \\
& 16=\text { Sophomore Year of College }
\end{aligned}
$$

Q51 Are both of your biological parents (or adoptive parents) still living?

$$
\begin{aligned}
& 1=\text { Yes (1) } \\
& 2=\text { No (2) }
\end{aligned}
$$

Answer: If "Are both of your biological parents (or adoptive parents)" No is selected.

Q51a Indicate which parent(s) is deceased and the month and year. Mother (MM/YYYY)

Father (MM/YYYY)

Q52 How long did you and both parents share a residence before you were 18? (include approximate number of years AND months)

Months - fill in number below

Years- fill in number below 
Q53 How long did you and your parents maintain separate residences before you were 18?

(include approximate number of years AND months)

Months- fill in number below

Years- fill in number below

Q54 What legal custody arrangement did your parents have?

Legal custody is the power to make legal decisions about things dealing with school and medical care.

Joint legal custody means they shared equal legal authority to make decisions.

Sole legal custody means that one parent was legally able to make all of the decisions and didn't have to talk to the other parents about it.

$1=$ Joint Legal Custody

2 = Sole Maternal Legal Custody

3 = Sole Paternal Legal Custody

$4=$ Not sure

Q55 What physical custody arrangement did your parents have?

Joint physical custody means that residential time was shared in some way between

parents/households or you all lived together.

Sole physical custody means that you lived with one parents and that the other parent only saw you when the parent you lived with allowed it (often called "visitation”).

$1=$ Joint Physical Custody

2 = Sole Maternal Physical Custody

3 = Sole Paternal Physical Custody

$4=$ Not sure

Q56 How would you describe the level of conflict your parents had regarding your care or discipline?

\begin{tabular}{|c|c|l|l|l|l|}
\hline & $\begin{array}{l}\text { Little to No } \\
\text { Conflict (1) }\end{array}$ & $\begin{array}{l}\text { Occasional } \\
\text { Conflict (2) }\end{array}$ & $\begin{array}{l}\text { Moderate } \\
\text { Conflict (3) }\end{array}$ & $\begin{array}{l}\text { Frequent } \\
\text { Conflict (4) }\end{array}$ & $\begin{array}{l}\text { Frequent and } \\
\text { Severe } \\
\text { Conflict (5) }\end{array}$ \\
\hline $\begin{array}{l}\text { Rate the level } \\
\text { of conflict. (1) }\end{array}$ & 1 & 2 & 3 & 4 & 5 \\
\hline
\end{tabular}

Answer: If "Were your parents ever separated before you were 18?" Yes is selected

Q57 The following questions are for individuals that indicated their parents separated before they were 18. Please just consider the first two years after your parents separated.

Childhood Residential Patterns with your Father.

Think about your residential patterns during the school year (not including breaks and holidays) the first two years after your parents separated.

How many nights a week on average did you spend at your father’s residence? 
For example if you spent Friday and Saturday nights at your father's residence every other weekend, then you spent an average of one night per week.

[drop down selection 1-7, 8= don't remember]

Answer: If “Were your parents ever separated before you were 18?” Yes is selected

Q58 On average, what weeknights did you spend at your father's house during the school year the first two years after their separation?

$$
\begin{aligned}
& 1=\text { Sunday night } \\
& 2=\text { Monday night } \\
& 3=\text { Tuesday night } \\
& 4=\text { Wednesday night } \\
& 5=\text { Thursday night } \\
& 6=\text { Don't remember }
\end{aligned}
$$

Answer: If "Were your parents ever separated before you were 18?" Yes is selected

Q59 On average, how often did you spend the weekend at your father's residence during the school year the first two years after their separation?

$$
\begin{aligned}
& 1=\text { Rarely or Never } \\
& 2=\text { One weekend a month } \\
& 3=\text { Every other weekend } \\
& 4=\text { Every weekend } \\
& 5=\text { Don't remember }
\end{aligned}
$$

Answer: If "Were your parents ever separated before you were 18?" Yes is selected

Q60 Childhood Residential Patterns with your Mother.

Think about your residential patterns during the school year (not including breaks and holidays) the first two years after your parents separated.

How many nights a week on average did you spend at your mother's residence?

For example if you spent Friday and Saturday nights at your mother's residence every other weekend, then you spent an average of one night per week.

$$
\text { [drop down selection 1-7, 8= don't remember] }
$$


Answer: If “Were your parents ever separated before you were 18?” Yes is selected

Q61 On average, what weeknights did you spend at your mother's house during the school year the first two years after separation?

$$
\begin{aligned}
& 1=\text { Sunday night } \\
& 2=\text { Monday night } \\
& 3=\text { Tuesday night } \\
& 4=\text { Wednesday night } \\
& 5=\text { Thursday night } \\
& 6=\text { Don't remember }
\end{aligned}
$$

Answer: If “Were your parents ever separated before you were 18?” Yes is selected

Q62 On average, how often did you spend the weekend at your mother's residence during the

\begin{tabular}{|c|c|c|c|c|c|c|}
\hline & $\begin{array}{c}\text { My time } \\
\text { with my } \\
\text { parents was } \\
\text { spent the } \\
\text { same way } \\
\text { that it was } \\
\text { during the } \\
\text { school year. } \\
1\end{array}$ & 2 & 3 & 4 & $\begin{array}{c}\text { My time } \\
\text { spent with } \\
\text { my parents } \\
\text { was very } \\
\text { different } \\
\text { during the } \\
\text { summer } \\
\text { months. } \\
5\end{array}$ & $\begin{array}{c}\text { I don't } \\
\text { remember. } \\
6\end{array}$ \\
\hline $\begin{array}{l}\text { How would } \\
\text { you describe } \\
\text { your time } \\
\text { during the } \\
\text { summer? (1) }\end{array}$ & 1 & 2 & 3 & 4 & 5 & 6 \\
\hline
\end{tabular}
school year the first two years after separation?

$$
\begin{aligned}
& 1=\text { Rarely or Never } \\
& 2=\text { One weekend a month } \\
& 3=\text { Every other weekend } \\
& 4=\text { Every weekend } \\
& 5=\text { Don't remember }
\end{aligned}
$$

Answer: If “Were your parents ever separated before you were 18?” Yes is selected

Q63 Childhood Summer Residential Patterns. For the following question think about your residential patterns during the summer the first two years after your parents separated. 
Q64 Overall Residence Pattern. How would you describe your residence patterns in your childhood? If your parents separated or divorced, think about the first two years after your parents separated.

\begin{tabular}{|c|c|c|c|c|c|}
\hline & $\begin{array}{l}\text { The living } \\
\text { arrangements } \\
\text { that I had were } \\
\text { stable and } \\
\text { predictable. } \\
1\end{array}$ & 2 & 3 & 4 & $\begin{array}{c}\text { The living } \\
\text { arrangements } \\
\text { that I had were } \\
\text { continually } \\
\text { changing and } \\
\text { unpredictable. } \\
5\end{array}$ \\
\hline $\begin{array}{l}\text { Rate your } \\
\text { Living } \\
\text { Arrangements. }\end{array}$ & 1 & 2 & 3 & 4 & 5 \\
\hline
\end{tabular}




\section{References}

Amato, P. R. (2010). Research on divorce: Continuing trends and new developments. Journal of Marriage and Family, 72, 650-666. doi:10.1111/j.1741-3737.2010.00723.x

Amato, P. R., \& Deboer, D. (2001). The intergenerational transmission of marital instability across generations: Relationship skills of commitment to marriage? Journal of Marriage and Family, 63, 1038-1051.

Amato, P. R., \& Soblewski, J. M. (2001). The effects of divorce and marital discord on adult children’s psychological well-being. American Sociological Review, 66, 900-921.

Amodeo, M., \& Griffin, M. (2009). Sibling agreement on retrospective reports of parental alcoholism and other childhood events. Substance Use \& Misuse, 44, 943-964. doi:10.1080/10826080802490709

Bartholomew, K. (1990). Avoidance of intimacy: An attachment perspective. Journal of Social and Personal Relationships, 7, 147-178.

Bartholomew, K., \& Horowitz, L. M. (1991). Attachment styles among young adults: A test of a four-category model. Journal of Personality and Social Psychology, 61, 226-244.

Bauserman, R. (2002). Child adjustment in joint-custody versus sole-custody arrangements: A meta-analytic review. Journal of Family Psychology, 16, 91-102. doi:10.1037//08933200.16.1.91

Berger, L., Brown, P., Joung, E., Melli, M., \& Wimer, L. (2008). The stability of child physical placements following divorce: Descriptive evidence from Wisconsin. Journal of Marriage and Family, 70, 273-283. doi:10.1111/j.1741-3737.2008.00480.x 
Bifulco, A., Brown, G.W., Lillie, A., Jarvis, J. (1997) Memories of childhood neglect and abuse: Corroboration in a serioes of sisters. Journal of Child Psychology \& Psychiatry, 38, 365374.

Bowlby, J. (1958). The nature of the child's tie to his mother. International Journal of Psychoanalysis, 39, 350-373.

Bowlby, J. (1969). Attachment and loss. New York: Basic Books.

Brennan, K. A., Clark, C. L., \& Shaver, P. R. (1998). Self-report measurement of adult attachment. In J. Simpson \& S. Rholes. (Eds.), Attachment theory and close relationships (pp. 46-76). New York: The Guilford Press.

Brewin, C., Andres, B., \& Gotlib, I. (1993). Psychopathology and early experience: A reappraisal of retrospective reports. Psychological Bulletin, 113, 82-98.

Bretherton, I. (2010). Father in attachment theory and research: A review. Early Child Development and Care, 190, 9-23. doi:10.1080/03004430903414661

Cartwright, C. (2006).You want to know how it affected me? Young adults’ perceptions of the impact of parental divorce. Journal of Divorce \& Remarriage, 44, 125-143. doi:10.1300/J087v44n03_08

Cashmore, J., Parkinson, P., \& Taylor, A. (2008). Overnight stays and children’s relationships with resident and nonresident parents after divorce. Journal of Family Issues, 29, 707733.

Cassidy, J. (2008). The nature of the child's ties. In J. Cassidy \& P. R. Shaver (Eds.), Handbook of attachment: Theory, research, and clinical applications ( ${ }^{\text {nd }}$ ed., pp. 3-22). New York: The Guilford Press. 
Coleman, L., \& Glenn F. (2010). The varied impact of couple relationship breakdown on children: Implications for practice and policy. Children and Society, 24, 238-249. doi:10.1111/j.1099-0860.2009.00289.x

Craig, G. J., \& Dunn, W. L. (2007). Understanding human development. Upper Saddle River, NJ: Pearson.

Crowell, J. A., Trebouz, D., \& Brockmeyer, S. (2009). Parental divorce and adult children’s attachment representations and marital status. Attachment \& Human Development, 11, 87-101. doi:10.1080/14313730802500867

Cui, M., \& Fincham, F. D. (2010). The differential effects of parental divorce an marital conflict on young adult romantic relationships. Personal Relationships, 14, 331-343. doi:10.1111/j.1475-6811.2010.01279.x

Cunningham, M., \& Thornton, A. (2005). The influences of parents' and offspring’s experience with cohabitation, marriage, and divorce on attitudes toward divorce in young adulthood. Journal of Divorce \& Remarriage, 44, 119-144. doi:10.1300/J087v44n0107

Dillman, D. A., Smyth, J. D., \& Christian, L. M. (2009).Internet, mail, and mixed-mode surveys: The tailored design method. (3 ed.). Hoboken, NJ: John Wiley \& Sons.

Dube, S. R., Willaimson, D. F. Thompson, T., Felitti, V. J., \& Anda, R. F. (2004). Assessing the reliability of retrospective reports of adverse childhood experiences among adult HMO members attending a primary care clinic. Child Abuse \& Neglect, 28, 729-737.

Faber, A. J., \& Wittenborn, A. K. (2010). The role of attachment in children's adjustment to divorce and remarriage. Journal of Family Psychotherapy, 21, 89-104. doi:10.1080/08975353.2010.483625 
Feeney, B. C., \& Monin, J. K. (2008) Attachment-theoretical perspective on divorce. In J. Cassidy \& P. R. Shaver (Eds.), Handbook of attachment: Theory, research, and clinical applications ( $2^{\text {nd }}$ ed., pp. 934-957). New York: The Guilford Press.

Hampton, K. N., Goulet, L. S., Rainie, L., \& Purcell, K. (2011). Social networking sites and our lives: How people’s trust, personal relationships, and civic and political involvement are connected to their use of social networking sites and other technologies. Retrieved from Pew Research Center’s Internet \& American Life Project website: http://beta.images.theglobeandmail.com/archive/01287/Pew_Study__Social__1287603a. pdf

Hans, J. D., \& Fine, M. A. (2002). Children of divorce: Experiences of children whose parents attended a divorce education program. Journal of Divorce \& Remarriage, 36, 1-26.

Hazan, C., \& Shaver, P. R. (1987). Romantic love conceptualized as an attachment process. Journal of Personality and Social Psychology, 52, 511-524.

Howes, C., \& Spieker, S. (2008). Attachment relationships in the context of multiple caregivers In J. Cassidy \& P. R. Shaver (Eds.), Handbook of attachment: Theory, research, and clinical applications (2 ${ }^{\text {nd }}$ ed., pp. 317-332). New York: The Guilford Press.

Kelly, J. B., \& Emery R. E. (2003). Children’s adjustment following divorce: Risk and resilience perspectives. Family Relations, 52, 352-362.

Kushner, M. A. (2009). A review of the empirical literature about child development and adjustment post separation. Journal of Divorce \& Remarriage, 50, 496-516. doi:10.1080/10502550902970595 
Lambert, A. N. (2007). Perceptions of divorce advantages and disadvantages: A comparison of adult children experiencing one parental divorce versus multiple parental divorces. Journal of Divorce \& Remarriage, 48, 55-77. doi:10.1300/J087v48n01_03

Rainie, L. (2010). Internet, broadband, and cell phone statistics. Retrieved from Pew Research Center's Internet \& American Life project website: http://www.pewinternet.org/Reports/2010/Internet-broadband-and-cell-phonestatistics/Report.aspx

Rutter, M., \& O’Connor, T.G. (1999). Implications of attachment theory for child care policies. In J. Cassidy \& P.R. Shaver (Eds.), Handbook of attachment: Theory research, and clinical applications (pp.823-844). New York: Guilford Press.

Sher, K. J., Descutner, C. (1986). Reports of paternal alcoholism: reliability across siblings. Addictive Behaviors, 11, 25-30.

Simpson, J. A., \& Rholes, W. S. (1998). Attachment in adulthood. In J. Simpson \& W. Rholes (Eds.),Attachment theory and close relationships (pp. 3-21). New York, NY: The Guilfod Press.

Teachman, J. D. (2008). The living arrangements of children and their educational well-being. Journal of Family Issues, 29, 734-761. doi:10.1177/0192513X07309742

Werner-Wilson, R. J., \& Davenport, B. R. (2003) Distinguishing between conceptualization of attachment: Clinical implications in marriage and family therapy. Contemporary Family Therapy, 25, 179-193. 


\section{VITA}

Katherine N. (Terrana) Washington was born August 7, 1986 in New Kensington, Pennsylvania

EDUCATION

Bachelor of Arts in Psychology from Grove City College (2009)

Minor: Family Studies

Minor: Sociology

PROFESSIONAL POSITIONS

Research and Teaching Assistant

University of Kentucky Family Sciences Department

Marriage and Family Therapy Intern

University of Kentucky Family Center

SCHOLASTIC PROFESSIONAL HONORS

Graduated Cum Laude from Grove City College

\section{PROFESSONAL PUBLICATIONS}

Haas, K. E., De Mers, M. R., Fulton, B., Terrana, K. N., \& Horton, J. J. (2010). Children’s attention to rules in sorting cards: Distinguishing between theories of cognitive development. Psi Chi Journal, 15, 8-12.

Werner-Wilson, R. J., Lianekhammy, J., Frey, L. M., Parker, T. S., Wood, N., Kimberly, C., Perry, M. S., Blackburn, K., Smith, L., Terrana, K., Puckett, J., \& Dalton, M. (2011). Alpha asymmetry in female military spouses following deployment. Journal of Feminist Family Therapy, 23, 202-217 